\title{
Democricetodon and Megacricetodon (Mammalia, Cricetidae) from the Miocene of Sandelzhausen, Southern Germany
}

\author{
Wilma Wessels · Barbara M. Reumer
}

Received: 28 July 2006/ Accepted: 21 December 2006/Published online: 18 February 2009

(C) The Author(s) 2009. This article is published with open access at Springerlink.com

\begin{abstract}
The cricetid species Democricetodon gracilis (Fahlbusch, 1964), Democricetodon mutilus (Fahlbusch, 1964), Megacricetodon bavaricus (Fahlbusch, 1964), and Megacricetodon minor (Lartet, 1851) from Sandelzhausen (Early/Middle Miocene boundary, MN5, Southern Germany) are represented by more than 2,000 molars providing substantial data on the variability in sizes and on variation in morphologies. Temporal and spatial distributions of these species indicate that they are probably immigrants in SE Germany, originating from south-eastern or more southern areas. Except for M. minor, whose origin is not clear and could be regarded as an immigrant from more eastern areas. Using the length of the mesoloph in the second upper molars as an indicator of habitat, D. gracilis and $M$. minor had a preference for a humid habitat, $D$. mutilus and M. bavaricus a preference for drier habitats.
\end{abstract}

Keywords Cricetidae - Democricetodon •

Megacricetodon · Germany · MN5 · Distribution ·

Paleoecology

Kurzfassung Die Hamster-Arten Democricetodon gracilis (Fahlbusch, 1964), Democricetodon mutilus (Fahlbusch, 1964), Megacricetodon bavaricus (Fahlbusch, 1964) und Megacricetodon minor (Lartet, 1851) sind durch

\footnotetext{
W. Wessels $(\bowtie)$

Department of Earth Sciences, Utrecht University, Budapestlaan 4, 3584 CD Utrecht, The Netherlands e-mail: wessels@geo.uu.nl

\section{B. M. Reumer}

Section of Animal Ecology, Institute of Biology, Leiden University, P.O. Box 9516, 2300 RA Leiden, The Netherlands

e-mail: B.Reumer@biology.leidenuniv.nl
}

mehr als 2000 Zähne in Sandelzhausen (Grenzbereich Unter-/Mittelmiozän, MN5, Süddeutschland) belegt und liefern umfangreiche Daten zur Kenntnis der Variabilität der Größe sowie der Morphologie. Die zeitliche und räumliche Verbreitung dieser fossilen Arten zeigen, dass sie wahrscheinlich aus südöstlichen oder mehr südlichen Gebieten nach Deutschland eingewandert sind. Eine Ausnahme könnte $M$. minor darstellen, dessen Herkunft nicht klar ist und vielleicht als ein Einwanderer aus östlichen Gebieten betrachtet werden könnte. Die Länge des Mesoloph am zweiten oberen Molar erlaubt Rückschlüsse auf bevorzugte Lebensräume und ergibt für $D$. gracilis und M. minor eine Vorliebe für ein eher feuchtes Habitat während $D$. mutilus und $M$. bavaricus offensichtlich trockenere Habitate bevorzugten.

Schlüsselwörter Cricetidae - Democricetodon ·

Megacricetodon · Deutschland · MN5 - Verbreitung ·

Palökologie

\section{Introduction}

The vertebrate fossil site Sandelzhausen is located in the Bavarian North Alpine Foreland Basin (Southern Germany), near the town of Mainburg, about $70 \mathrm{~km}$ north of Munich. The limnofluvial deposits of Sandelzhausen belong to the Upper Freshwater Molasse and were referred to the European Mammal Neogene Unit MN5 by Heissig (1997) with an absolute age of about $16 \mathrm{Ma}$. Based on recent bio-, litho- and magnetostratigraphic investigations the stratigraphic position of the locality, Sandelzhausen is situated at or very close to the Early/Middle Miocene boundary (Karpatian/Badenian boundary) (see Moser et al. 2009 this volume). 
The family Cricetidae is represented in the fossil fauna from Sandelzhausen by three genera: Democricetodon Fahlbusch 1964, Megacricetodon Fahlbusch 1964, and Eumyarion Thaler 1966, each represented by two species (for Eumyarion see de Bruijn 2009 this volume).

Fahlbusch (1964) described several new cricetid species from the Upper Freshwater Molasse from Southern Germany, among them: Democricetodon gracilis, D. mutilus, Megacricetodon bavaricus and M. minor. The Democricetodon species differ mainly in size, as do the Megacricetodon species. Sandelzhausen is the type locality of D. gracilis and with more than 1,000 molars D. mutilus is the best represented cricetid in Sandelzhausen.

The large quantity of the material enables us to describe a more precise ratio between the morphological characteristics and to determine the variability in size of the molars. M. bavaricus was not previously described from Sandelzhausen.

\section{Materials and methods}

From the 2,178 molars belonging to Democricetodon and Megacricetodon, 2,038 complete and only slightly worn molars were measured and their characteristics were used in the descriptions. Lower molars are indicated by $\mathbf{M}_{1,2,3}$, upper molars by $\mathrm{M}^{1,2,3}$. sin: sinister, dex: dexter.

Nomenclature used for part of the cheek teeth is after Mein and Freudenthal (1971), except for the terms ectoloph $=$ paracone $\quad$ spur and ectolophid/entoloph $=$ longitudinal crest. Added terms are anteroloph and anterolophid. The labial anteroloph descends from the anterocone $\left(\mathrm{M}^{1}\right)$ or from the centre of the tooth $\left(\mathrm{M}^{2}, \mathrm{M}^{3}\right)$ along the border of the molar to the paracone. The lingual anteroloph descends from the anterocone $\left(\mathrm{M}^{1}\right)$ or the centre of the tooth $\left(\mathrm{M}^{2}, \mathrm{M}^{3}\right)$ along the border of the molar to the protocone. The lingual anterolophid descends from the anteroconid $\left(\mathrm{M}_{1}\right)$ or the centre of the tooth $\left(\mathrm{M}_{2}, \mathrm{M}_{3}\right)$ along the border of the molar to the metaconid. The labial anterolophid descends from the anteroconid $\left(\mathrm{M}_{1}\right)$ or the centre of the tooth $\left(\mathrm{M}_{2}, \mathrm{M}_{3}\right)$ along the border of the molar to the protoconid.

The measurements were taken with a Leitz Ortholux microscope with a mechanical stage and measuring clocks. All measurements are given in $1 \mathrm{~mm}$ units. The molars figured are all from the left side. If the original is from the right side it is indicated in the figure caption.

The material is kept in the collections of the Bayerische Staatssammlung für Paläontologie und Geologie in Munich (BSPG). The fossil material of Sandelzhausen is registered under the complete inventory numbers
BSPG 1959 II $x x x x$. In the following text the prefix is deleted.

The geographical distributions and biochronological ranges are from Freudenthal and Daams (1988), Schötz (1993), Heissig (1997), Kälin (1997), Theocharopoulos (2000), Fortelius (2003), and Hír (2004).

\section{Systematic palaeontology}

Fahlbusch (1964) separated the (sub)genera Democricetodon and Megacricetodon from Cricetodon Lartet 1851 and described several new (sub)species. Democricetodon gracilis has Sandelzhausen as its type locality. The original description of Fahlbusch was based on 15 molars from Sandelzhausen and 61 molars from six other localities. Now, the current assemblage of Sandelzhausen contains more than 750 molars of $D$. gracilis and the variability in morphology and size can be described more precisely.

Order Rodentia Bowdich 1821.

Family Muridae Illiger 1811.

Subfamily Cricetodontinae Schaub 1925.

Genus Democricetodon Fahlbusch 1964.

\section{Democricetodon gracilis Fahlbusch 1964}

Figure $3 \mathrm{~A}-\mathrm{L}$.

1961 Cricetodon aff. bourgeoisi Schaub.-Dehm: 38. *1964 Democricetodon (Democricetodon) minor gracilis nov. subsp. Fahlbusch: 25-31, text-Figs. 10, 12, 13, 15, pl. 2 Figs. 5-22.

Holotype

Right M$_{1}$ (BSPG 1959 II 247), BSPG Munich, Germany.

Type locality and type horizon

Sandelzhausen (Southern Germany, Bavaria), OSM (Upper Freshwater Molasse), Early/Middle Miocene boundary (Karpatian/Badenian), MN5 (see Moser et al. 2009 this volume).

Geographical distribution and biochronological range

Greece (MN4), Germany (MN4-5), Switzerland (MN4-5), Turkey (MN4-5), Austria (MN4-5), Czech Republic (MN5), and Poland (MN6). 
Original diagnosis (translated from German, Fahlbusch 1964)

A form related to Democricetodon minor, with a smaller size and a more elegant appearance. Lower molars: sides of the crown near the labial and lingual sinus in most molars somewhat concave. Anteroconid of $\mathrm{M}_{1}$ mostly very short, forming a flat triangle. Mesolophid very short to half long at most. Metaconid often curved to the front. Upper molars: labial side of the crown mostly undulatory. Anterocone relatively narrow and undivided. Mesoloph long, often reaching the tooth border.

Material and measurements

A total of 767 molars, 727 complete and used in measurements and descriptions (see Figs. 1, 2, 3, Table 1).

$\mathrm{M}_{1} \operatorname{dex}(103,107,108,112,115-117,120-121,126-$ 129, 132, 134, 137-143, 146, 148, 5514, 6691, 6863, 7298, 7300, 9311-9330, 9332-9336, 9338-9353); $\mathrm{M}_{1} \sin (101-$ 102, 104-106, 109-111, 113-114, 118-119, 122-125, 130-131, 133, 135-136, 144, 147, 149, 151-158, 5515, 6689-6690, 6692, 7296-7297, 7299, 7301, 9283-9310, 9355-9357, 10231), $\mathrm{M}_{2}$ dex (6698, 6701-6702, 6705, 6707, 6709-6715, 6717, 6724, 6728, 6730, 6734-6735, 6737, 6739-6744, 6746-6748, 6752, 6756, 7304-7306, 7446, 7934, 9911, 9913, 9967, 9969-9973, 9975-9986, 9988, 9989, 9991-9993,9995-10001, 10004-10007, $10009,10012-10014) ; M_{2} \sin (6693,6697,6699-6700$, 6703-6704, 6706, 6708, 6716, 6718, 6721-6723, 67256727, 6729, 6731-6733, 6736, 6738, 6745, 6749, 6751, 6753, 6755, 6759, 7302-7303, 9916-9917, 9919-9926, 9928-9956, 9958-9959, 9961-9964, 9966, 10168, 1085610857, 10859, 10873, 10995-10996); $\mathrm{M}_{3} \operatorname{dex}(10169$, 10171-10173, 10175-10192, 10195-10198, 10200-10201, 10203-10207, 10209, 10220-10222, 10224-10226, 11046, 11185-11190, 11262, 11265-11266, 11268-11273, 11275), $\mathrm{M}_{3} \sin (10139-10156,10158-10164,10167$, 10212, 10214-10215, 10217, 10992-10993, 11175-11177, $11179-11183,11246,11248-11259) ; \mathrm{M}^{1} \operatorname{dex}(159-161$, 164-168, 170-171, 173, 176-177, 179, 181-182, 184-185, 187, 190-191, 195-198, 5508, 6667, 6670, 6674, 66776678, 6681-6682, 6684, 6688, 7308-7309, 9110-9145); $\mathrm{M}^{1} \sin (162-163,167,169,175,180,183,186,188-189$, 192-194, 199-200, 6666, 6668, 6669, 6671, 6672-6673, 6675-6676, 6680, 6683, 6685-6687, 7307, 7310-7311, 9081, 9084, 9075-9100, 9101-9109), $\mathrm{M}^{2} \operatorname{dex}(6761-6762$, 6766, 6769, 6772-6775, 6778-6782, 6784-6785, 6790, 6793, 6798, 6801, 6803-6804, 6806, 6808, 6811-6812, 6814-6815, 6820, 6826-6827, 7312-7313, 9778-9785, 9787-9801, 9803-9809, 9811-9813, 9815-9817, 10999); $M^{2} \sin (6763-6764,6767,6770-6771,6776-6777,6783$, 6786-6789, 6791, 6794-6797, 6799-6800, 6802, 6805,
6807, 6809-6810, 6813, 6816-6819, 6821, 6823, 68286830, 9737-9743, 9745-9748, 9750-9756, 9758-9760, 9761, 9763-9764, 9766-9777, 10229); $\mathrm{M}^{3} \operatorname{dex}(10640-$ 10663, 11174, 11244-11245); $\mathrm{M}^{3} \sin (10603-10632$, 10634-10639, 10720, 11010-11012, 11014, 11019, 11021, 11025-11026, 11236-11243).

The original description (Fahlbusch 1964) included 15 molars from Sandelzhausen; these are not included in the material described below.

\section{Description}

$\mathrm{M}^{1}(n=132)$ : The anterocone is for its largest part placed on the labial side of the molar. The labial side of the outline is straight, the lingual side is convex, transition from anterocone to protocone is smooth, indentations are absent. The anterocone is simple in 117 , superficially split in 14 and double in 1. A strong labial anteroloph connects the labial anterocone cusp to the paracone. The lingual anteroloph is low and short in 114 (it is not connected to the lingual base of the protocone) and it is long and connected to the protocone in 18. An anterolophule connects the lingual anterocone cusp to the protocone. A labial spur of the anterolophule is present in 21 (5 very short, 13 short, long in 3). The protolophule is double in 56 (13 incomplete) and simple in 64 (in 3 transverse and connected to the middle of the protocone, in 61posterior and connected to the longitudinal crest behind the protocone). In 12 a short transverse spur is present in the anterosinus, but it is unclear whether it is a protolophule or a spur of the anterolophule. The metalophule is connected to the posteroloph in 115 , connected to the hypocone in 5 , double in 9 (in 4 incomplete) and absent in 3. The mesoloph is always present, short in 6 , of medium length in 32 and long in 94 (in 41 connected to the labial border). A mesostyl is present in 13. Protocone spur and paracone spur are absent. A cusp (35) or ridge (80) is present on the antero-lingual base of the hypocone. This ridge is long in 6 and connected to the protocone closing the sinus. The sinus is transverse.

$\mathrm{M}^{2}(n=135)$ : The lingual anteroloph reaches the antero-lingual border of the protocone in 67, it is short in 53 and absent in 15. The labial anteroloph is long and joins the paracone. The protolophule is double in most molars (132) and single in 3 (in 2 connected to the antero-lingual border of the protocone, in 1 connected to the longitudinal crest behind the protocone). The metalophule is simple in 128 (anterior in 71, transverse in 34 , and posterior in 23), double in 5 and absent in 2. A mesoloph is always present, short in 1, of medium length in 14 and long in 120 (in 90 connected to the labial border). Protocone spur and paracone spur are absent. A ridge is present (in all but one) on the antero-lingual base of the hypocone, in 41 it is long, connected to the protocone and 
closing the sinus. A mesostyl is present in 41 . The sinus is transverse.

$\mathrm{M}^{3}(n=68)$ : The labial anteroloph joins the anterolabial side of the paracone. The lingual anteroloph reaches the basis of the protocone in 18 , it is not connected to the protocone in 38 and absent in 12. A hypocone is large in 32 , small in 25 and absent in 11. A metacone is present in 13 (3 large), in all the other molars the metacone is incorporated into the ridge on the tooth border. The hypocone and "metacone" are connected by a posteroloph and a metalophule. The metalophule is either semicircular or straight (absent in 2). A complete ridge between paracone and metalophule is present in 37 , an incomplete one (often cusplike) in 12, a ridge between paracone and hypocone is present in 2 and a ridge from the centre of the anteroloph joins the metalophule in 3. A labial spur on this connection is present in 24 and a labial spur on the metalophule is present in 12 . The sinus is deep in 1 , shallow in 18 , very shallow in 24 and absent in 25 .

$\mathrm{M}_{1}(n=134)$ : The anteroconid is always simple and near to protoconid and metaconid. The labial anterolophid is low and joins the base of the protoconid. Due to the lack of an lingual anterolophid (absent in all but 18), anteroconid and metaconid are not connected, not even when worn. In 18, a short lingual anterolophid is present, here anteroconid and metaconid fuse in wear. The anterolophulid is short in 131 and is absent in 3 (the anteroconid is then an isolated cusp). The metalophulid is anterior in 102, transverse in 21, absent in 10 and double in 1. The hypolophulid is anterior in 72 , transverse in 61 , and absent in 1. The mesolophid is absent in 31 , short in 60 , of medium length in 32 and long in 11 ( 1 connected to the border). In 1 tooth an extra spur is present parallel to the short mesolophid. An ectomesolophid is absent. The sinusid is forwards directed, it has a small cusp in its centre in 2 and is closed by a ridge in 7 .

$\mathrm{M}_{2}(n=152)$ : The labial anterolophid joins the anterolabial border of the protoconid in 8 , it is not connected to the protoconid in 55 and absent in 89 . The lingual anterolophid is strong in 43 (a narrow valley is present between anterolophid and metaconid), weak in 86 (fuses in early wear with metaconid) and absent in 23. An anterior metalophulid is present in 144, a transverse metalophulid in 1 and a double metalophulid 7 (here the posterior branch is in 5 connected to the mesolophid, in 2 of these also an extra ridge on the entoconid is present). The hypolophulid is anterior in all but 2, where it is transverse. The mesolophid is absent in 16, short in 74, of medium length in 48 and long in 14 ( 2 of these are connected to the border). An ectomesolophid is present in 1, strong on its labial part and weak where it joins the longitudinal crest. The sinusid is forwards directed and in 8 closed by a strong ridge on the border of the molar.
Fig. 1 Scatter diagrams of L/W ratios (length/width in $\mathrm{mm}$ ) of upper (M1/, M2/, M3/) and lower molars (M/1, M/2, M/3) of triangle Democricetodon gracilis and diamond Democricetodon mutilus

$\mathrm{M}_{3}(n=106)$ : The labial anterolophid is connected to the antero-labial border of the protoconid in 11, short and not connected to the protoconid in 36 and absent in 59. The lingual anterolophid is strong in 38 (a narrow valley is present between anterolophid and metaconid), weak in 59 (anterolophid and metaconid fuse in early wear) and absent in 9. The metalophulid is anterior in 86, transverse in 19 and absent in 1 . The longitudinal crest is in all but 5 semi-circular and connected to the lingual border by a short hypolophulid. The point where the hypolophulid joins the lingual cingulum is slightly thickened and the sinusid is transverse or slightly backwards directed. In 5 the longitudinal crest is angular, connected to the lingual border at its apex and the sinusid is deep. A short mesolophid-like ridge is present in 4. The sinusid has in 9 a ridge or a small cusp on the occlusal border.

\section{Discussion}

The now available large number of molars from Sandelzhausen gives a better insight in the variation in characteristic features of Democricetodon gracilis. Compared to the original description, the mesolophid shows a larger variation: absent in $23 \% \mathrm{M}_{1}$ and in $11 \% \mathrm{M}_{2}$, long or connected to the lingual border in $7.5 \% \mathrm{M}_{1}$ and $9 \% \mathrm{M}_{2}$. The metalophulid and hypolophulid are in the $M_{1}$ not always parallel, the metalophulid is transverse in $15 \%$ and absent in 7\%. The labial branch of the anterolophid in the $\mathrm{M}_{3}$ is absent in more than $50 \%$ of the molars. The protolophule in $\mathrm{M}^{1}$ is double in almost $40 \%$ and in the $\mathbf{M}^{2}$ is almost always double. In most $\mathrm{M}^{3}$ the hypocone (either small or large) is present, a metacone is present in almost $20 \%$ and a lingual branch of the anteroloph is either short or absent $(74 \%)$. The measurements of the "new" Sandelzhausen material completely overlap the original measurements.

The range in size in D. gracilis from Sandelzhausen overlaps almost completely all other $D$. gracilis measurements from other localities (probably due to the very large amount of molars). A general description of D. gracilis, based on the most common occurrences of some characteristics gives us the following description: The mesoloph is of medium length or long in $\mathrm{M}^{1}$, long or connected to the border in $\mathrm{M}^{2}$, the mesolophid is of medium length or short in $\mathrm{M}_{1}$ and short in the $\mathbf{M}_{2}$. The protolophule is simple in $\mathrm{M}^{1}$ and double in $\mathrm{M}^{2}$. The metalophule is in $\mathrm{M}^{1}$ posterior and in $\mathrm{M}^{2}$ anterior or transverse. Only the oldest $D$. gracilis from Aliveri (Greece) has a double protolophule in most 

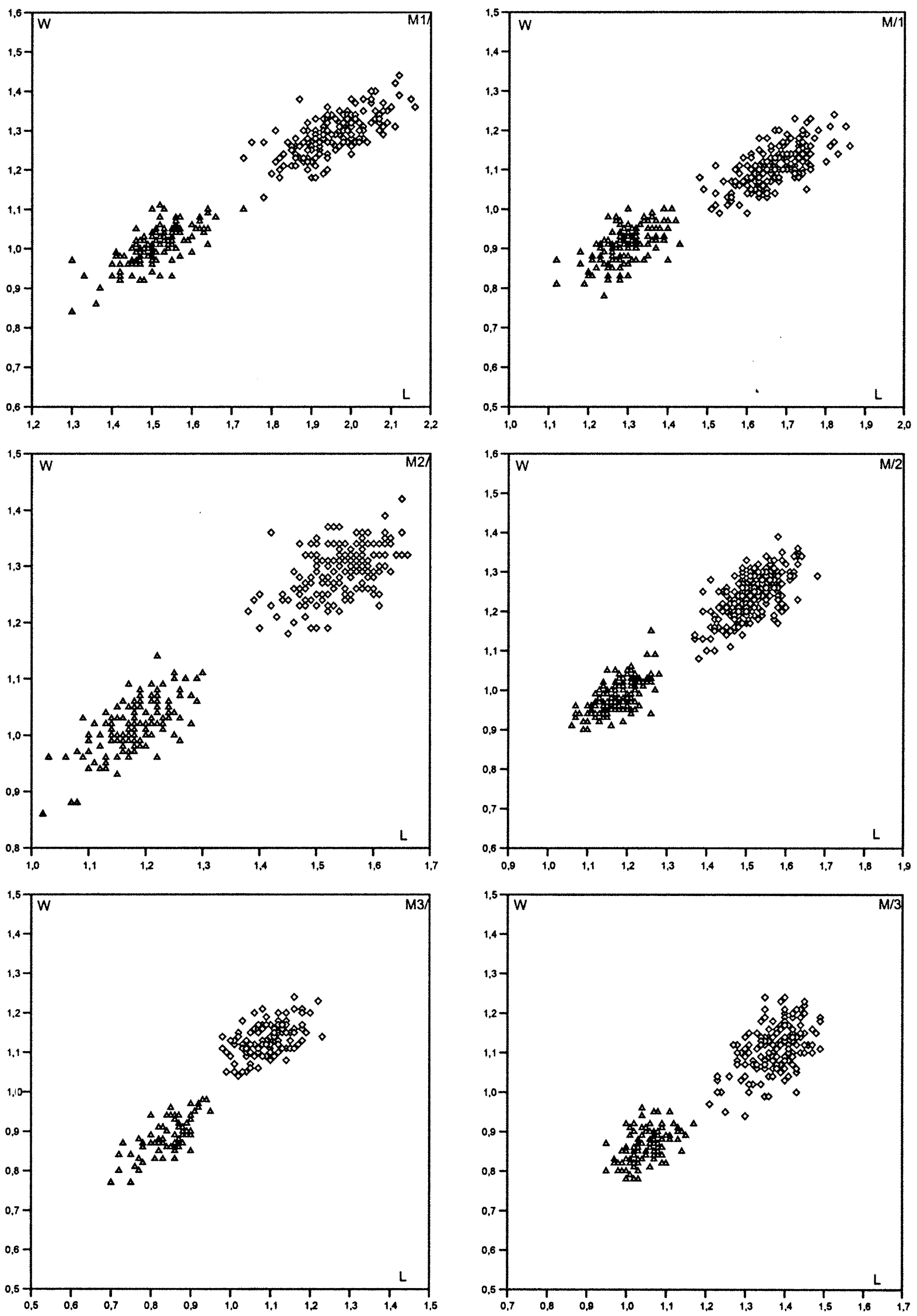
$M^{1}(75 \%)$, but otherwise its characteristics are within the general variation.

\section{Democricetodon mutilus Fahlbusch 1964}

Figure 4A-L.

*1964 Democricetodon (Democricetodon) affinis mutilus

FAHLBusCh: 36, text-figs. 20-27, pl. 3 Figs. 1-22.

\section{Holotype}

Left $M_{1}$ (1951 XXVII 100), BSPG, Munich, Germany.

Type locality and type horizon

Langenmoosen near Neuburg/Donau (Germany), OSM (Upper Freshwater Molasse), Middle Miocene, MN5.

Geographical distribution and biochronological range

France (MN4-5), Austria (MN5), Switzerland (MN5-6), Germany (MN5-7/8), and Hungary (MN7/8).

Material and measurements

A total of 1,041 molars, 973 complete and used in measurements and descriptions (see Figs. 1, 4, Table 2).

$M_{1} \operatorname{dex}(145,6832-6833,6836-6839,6841-6843,6846$, $6848,6850-6852,6858,6860-6862,6865,6867,6869-$ 6871, 6873-6876, 6879-6883, 6886, 6891, 6893-6896, 6898-6899, 6903-6904, 6906, 6908, 6910-6911, 69146915, 7316-7319, 7324, 7326, 9403-9435, 9337); $M_{1} \sin$ (150, 5509, 6831, 6834-6835, 6840, 6844-6845, 6847, $6849,6853-6857,6859-6864,6866,6868,6872,6877-$ 6878, 6884-6885, 6887-6890, 6892, 6897, 6900-6902, 6905, 6907, 6909, 6912-6913, 7314-7315, 7320-7323, 7325, 7327-7328, 9354, 9358-9402); $\mathrm{M}_{2} \operatorname{dex}(7025-7027$, $7029,7434,7436,7438-7440,7444,7449-7450,7452-$ $7453,7457,7459-7460,7462,7464,7467-7468,7470-$ 7472, 7474-7477, 7480-7481, 7484, 7486, 7488-7490, 7492-7786, 7788-7790, 7792-7793, 7795-7800, 7907, 7911-7912, 7916, 7920, 7923-7925, 7933, 7936-7937, 9855-9895); $\mathrm{M}_{2} \sin (5510,7021-7022,7024,7028,7030$, 7429-7433, 7435, 7437, 7441-7443, 7445, 7447-7448, 7451, 7454-7456, 7458, 7461, 7463, 7465-7466, 7469, 7473, 7478-7479, 7482-7483, 7485, 7487, 7491, 74977500, 7785, 7787, 7791, 7794, 7799, 7906, 7908-7910, 7913-7915, 7917-7919, 7921-7922, 7926-7932, 7935, 7938, 9818-9854, 10985-10986); $\mathrm{M}_{3}$ dex (10099-10138, 10199, 11135-11173, 11184); $\mathrm{M}_{3}$ sin (10057-11134, 11178); $\mathrm{M}^{1}$ dex (174, 7012-7014, 7017-7020, 7330, 7334, 7335, 7339, 7342-7343, 7345, 7348-7352, 7354,
Fig. 2 Scatter diagrams of L/W ratios (length/width in $\mathrm{mm}$ ) of upper (M1/, M2/, M3/) and lower molars (M/1, M/2, M/3) of circle Megacricetodon minor and square Megacricetodon bavaricus

7357-7358, 7360, 7366-7367, 7372, 7374-7377, 7379, 7381-7383, 7386, 7388, 7391-7392, 7394-7396, 73987400, 7404, 7406, 7409-7410, 7413, 7415, 7419, 74207423, 7425-7428, 9181-9215, 10230); $\mathrm{M}^{1} \sin (178,5517$, 6679, 7011, 7015, 7331-7333, 7336-7338, 7340-7341, 7344, 7346-7347, 7353, 7355-7356, 7359, 7361-7371, 7373, 7378, 7380, 7384-7385, 7387, 7389, 7390, 7393, 7397, 7401-7405, 7407-7408, 7411-7412, 7414, 74167418, 7424, 9146-9180); $\mathrm{M}^{2} \operatorname{dex}(6792,6824-6825,7941$, 7944, 7947-7953, 7959, 7961-7962, 7964-7967, 7969, 7972-7973, 7977-7978, 7980, 7984-7985, 7987-7988, 7990-7997, 8001-8004, 8007, 8010, 8012-8015, 8018$8019,8021,8023,8025-8026,8029,7031-7032,7034$ 7037, 7039, 9696-9735); $\mathrm{M}^{2} \sin (6822,7942-7943,7945$, 7954-7958, 7960, 7963, 7968, 7970-7971, 7974-7976, $7979,7981-7983,7986,7989,7995,7998-8000,8005-$ 8006, 8008-8009, 8011, 8016-8017, 8020, 8022, 8024, 8027-8028, 8030, 7033, 7038, 7040, 9663-9695); $\mathrm{M}^{3} \mathrm{dex}$ (10736-10777, 11214-11235); $\mathrm{M}^{3} \sin (10633,10704$ 10735, 10778-10780, 11191-11213).

In the original species description (Fahlbusch 1964) 40 molars from Sandelzhausen were included.

\section{Description}

$\mathrm{M}^{1}(n=154)$ : The anterocone is for its largest part placed on the labial side of the molar. The labial side of the outline is straight, the lingual side is convex, transition from anterocone to protocone is smooth in 61, with a small indentation near the protosinus in 71 and a stronger one in 22. The anterocone is simple in all molars. A strong labial anteroloph connects the labial anterocone cusp to the paracone. The low lingual anteroloph does not reach the lingual base of the protocone. An anterolophule connects the lingual anterocone cusp to the protocone. A labial spur of the anterolophule is present in 22 (21 short and long in 1). The protolophule is double in 48 (15 incomplete) and simple in 99 (transverse in 1and connected to the middle of the protocone, posterior in the others and connected to the longitudinal crest behind the protocone). In 7 a short transverse spur is present in the anterosinus, but it is unclear whether it is a protolophule or a spur of the anterolophule. The metalophule is simple in 140 (anterior in 4 and connected to the hypocone, posterior in 136 and connected to the posteroloph), double in 1 and absent in 13 . The mesoloph is always present, short in 29 , of medium length in 90 and long in 35 (in 3 connected to the labial border). Protocone spur and paracone spur are absent. The sinus is transverse. A cusp (2) or ridge (80) is present on 

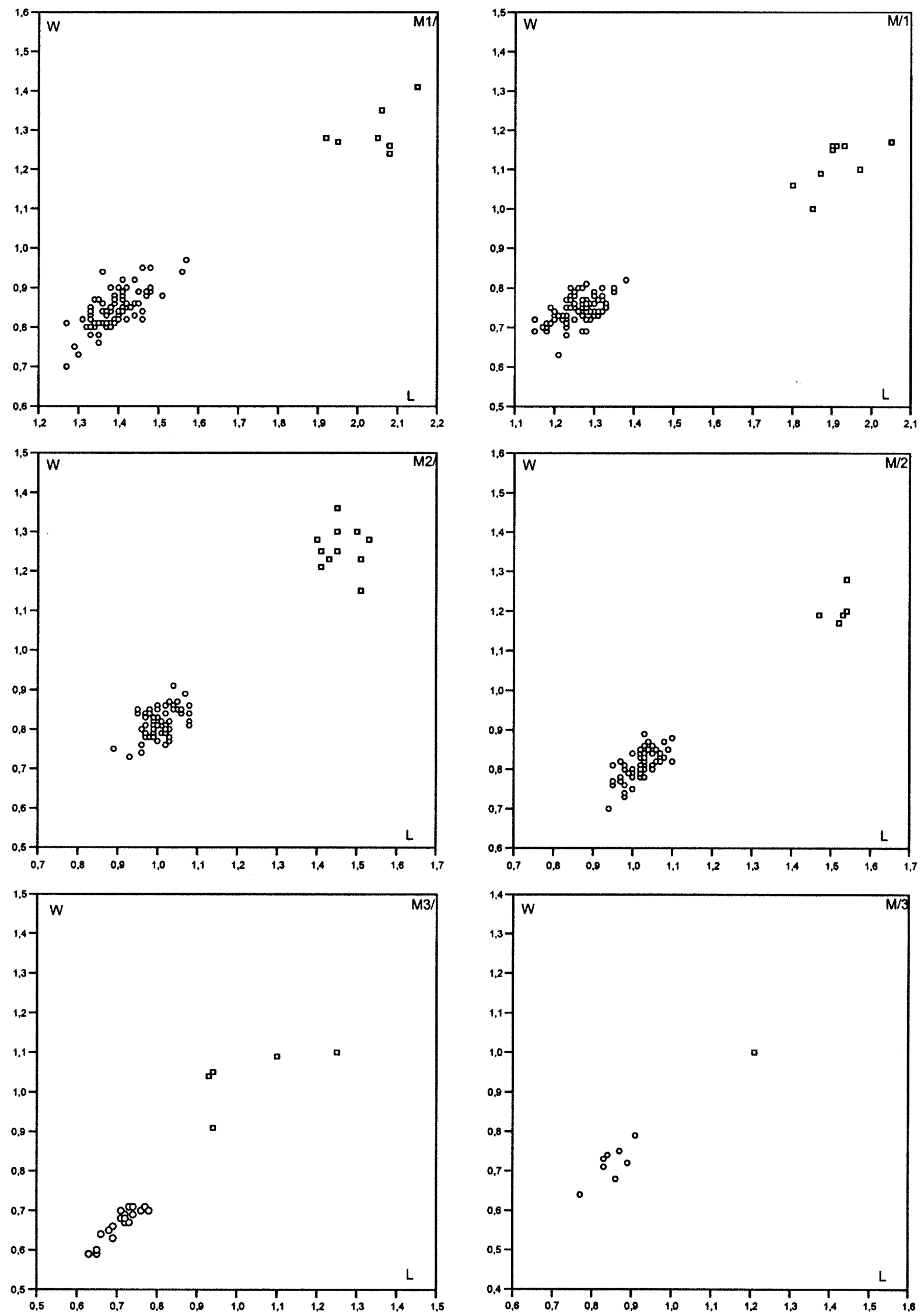

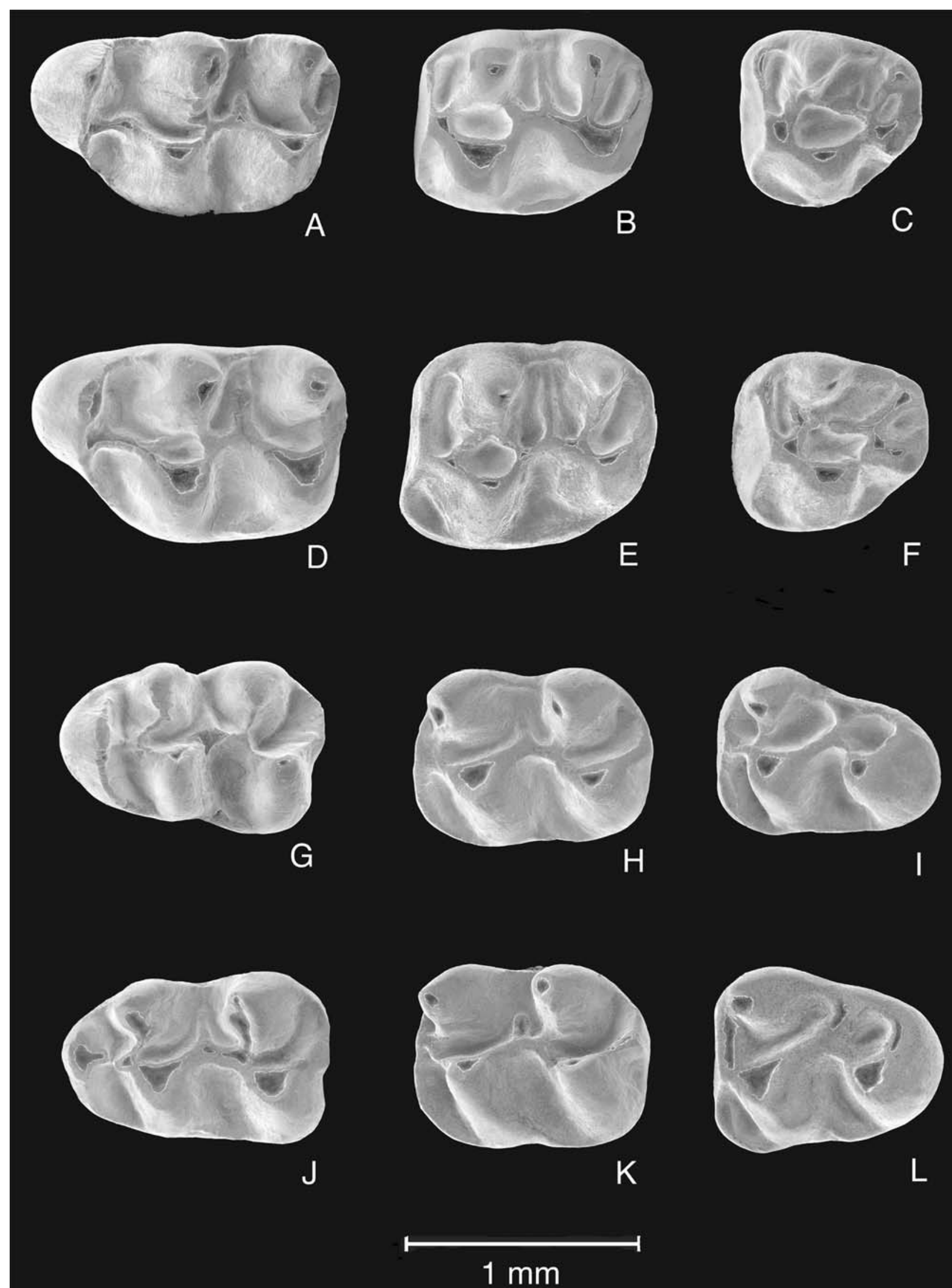
Fig. 3 Molars (in occlusal view) of Democricetodon gracilis from Sandelzhausen (Southern Germany, MN5). A $\mathrm{M}^{1}$ (7307); B $\mathrm{M}^{2}$ (9773); $C \mathrm{M}^{3}$ (10631); $D \mathrm{M}^{1}$ (6680); $E \mathrm{M}^{2}$ (6776); $F \mathrm{M}^{3}$ (10626); $G$ $\mathrm{M}_{1}$ (144); $H \mathrm{M}_{2}$ (6703); $I \mathrm{M}_{3}$ (11179); $J \mathrm{M}_{1}$ (7296); $K \mathrm{M}_{2}$ (9932); $L$ $\mathrm{M}_{3}$ (11251) All figured teeth are left specimens

the antero-lingual base of the hypocone. In 31 this ridge is long and connected to the protocone. A mesostyl is absent.

$\mathrm{M}^{2}(n=174)$ : The lingual anteroloph reaches the antero-lingual border of the protocone in 86 , it is short in 72 and absent in 16. The labial anteroloph is long and joins the paracone. The protolophule is double in most molars (164) and single in 10 (anterior in 3 and connected to the anterolingual border of the protocone, posterior in 7 and connected to the longitudinal crest). The metalophule is simple in 150 (anterior in 87, transverse in 17, posterior in 46), double in 15 and absent in 9. A mesoloph is present in all but 1 , short in 37 , of medium length in 85 and long in 51 (in 19 connected to the labial border). A mesostyl is present in 1. Protocone spur and paracone spur are absent. The sinus is transverse or slightly backwards directed, a ridge on the lingual border closes the sinus in 89 molars.

$\mathrm{M}^{3}(n=114)$ : The labial anteroloph joins the anterolabial side of the paracone, the lingual anteroloph reaches the basis of the protocone in 39, in 54 it is not connected to the protocone and is absent in 21. A hypocone is large in 25 , small in 51 and absent in 38. A metacone is distinguishable in 15 only, in all the other molars the metacone is incorporated into the lingual cingulum. The hypocone and 'metacone' are connected by a posteroloph and a metalophule. The metalophule is either semicircular or straight. A complete ridge between paracone and metalophule is present in 57, an incomplete one in 37. A labial spur on this ridge is present in 31 (17 to labial border) and a labial spur on the metalophule is present in 23. A proper double protolophule (configuration as in the $\mathrm{M}^{2}$ ) is present in 12 (in 3 of these a spur connects paracone also to metalophule). The sinus is deep in 3 , shallow in 48 , very shallow in 53 and absent in 10 .
$\mathrm{M}_{1}(n=167)$ : The anteroconid is always simple and near to protoconid and metaconid. A lingual anterolophid is absent in 94, low in 68 (joins the basis of the metaconid) and strong in 5 (anteroconid and metaconid are fused in middle wear). The anterolophulid is always short. The metalophulid is anterior in 150, transverse in 2 and absent in 15 . The hypolophulid is anterior in 108, transverse in 58 and absent in 1 . The mesolophid is absent in 2, short in 29, of medium length in 76 and long in 60 (18 connected to the border). An ectomesolophid is present in 45, strong in 13 and weak or short in 22. The sinusid is forwards directed, a ridge or cusp on the border is present in 6 .

$\mathrm{M}_{2}(n=208)$ : The labial anterolophid reaches the antero-labial border of the protoconid in 17, it is not connected to the protoconid in 83 and is absent in 108. The lingual anterolophid is strong in 32 (a narrow valley is present between anterolophid and metaconid), weak in 147 (anterolophid and metaconid fuse in early wear) and absent in 29. The metalophulid is forwards directed in all but 1 , where it is absent. The hypolophulid is in all forwards directed. The mesolophid is absent in 19, short in 63, of medium length in 108 and long in 18 (in 0 connected to the border). A very weak ectomesolophid is present in 2 . The sinusid is transverse or slightly forwards directed, it is closed by a strong ridge on its border in 9 .

$\mathrm{M}_{3}(n=156)$ : The lingual anterolophid is strong in 17 (a narrow valley is present between anterolophid and metaconid), weak in 94 (anterolophid and metaconid fuse in early wear) and absent in 45. The labial anterolophid is connected to the antero-labial border of the protoconid in 5, short and not connected to the protoconid in 38 and absent in 113. The metalophulid is forwards directed in 84 and transverse in 72. The longitudinal crest is asymmetric, its anterior part is strong in contrast to its posterior part which is less strong. A short hypolophulid joins the longitudinal crest (anterior part) to the lingual border in 113. Here the sinusid is transverse or slightly curved backward. In 43, a hypolophulid is absent and the posterior part of the longitudinal crest is also connected to the lingual border at or

Table 1 Measurements (in mm) of Democricetodon gracilis from Sandelzhausen

\begin{tabular}{|c|c|c|c|c|c|c|c|c|c|c|c|c|}
\hline \multicolumn{13}{|c|}{ Democricetodon gracilis } \\
\hline & \multirow[t]{2}{*}{ Total $(N)$} & \multicolumn{5}{|c|}{ Length } & \multirow[t]{2}{*}{$N$} & \multicolumn{5}{|c|}{ Width } \\
\hline & & Min & Mean & $\operatorname{Max}$ & SE & SD & & Min & Mean & $\operatorname{Max}$ & SE & SD \\
\hline $\mathrm{M}^{1}$ & 141 & 1.30 & 1.52 & 1.66 & 0.006 & 0.072 & 132 & 0.84 & 1.01 & 1.11 & 0.004 & 0.050 \\
\hline $\mathrm{M}^{2}$ & 140 & 1.02 & 1.18 & 1.30 & 0.005 & 0.053 & 135 & 0.86 & 1.02 & 1.14 & 0.004 & 0.048 \\
\hline $\mathrm{M}^{3}$ & 80 & 0.70 & 0.84 & 0.94 & 0.006 & 0.053 & 68 & 0.77 & 0.89 & 0.98 & 0.005 & 0.047 \\
\hline $\mathrm{M}_{1}$ & 141 & 1.12 & 1.30 & 1.43 & 0.005 & 0.058 & 134 & 0.78 & 0.91 & 1.00 & 0.004 & 0.046 \\
\hline $\mathrm{M}_{2}$ & 156 & 1.06 & 1.18 & 1.28 & 0.004 & 0.047 & 152 & 0.90 & 0.98 & 1.15 & 0.003 & 0.040 \\
\hline $\mathrm{M}_{3}$ & 109 & 0.95 & 1.05 & 1.17 & 0.004 & 0.045 & 106 & 0.78 & 0.86 & 0.96 & 0.004 & 0.041 \\
\hline
\end{tabular}



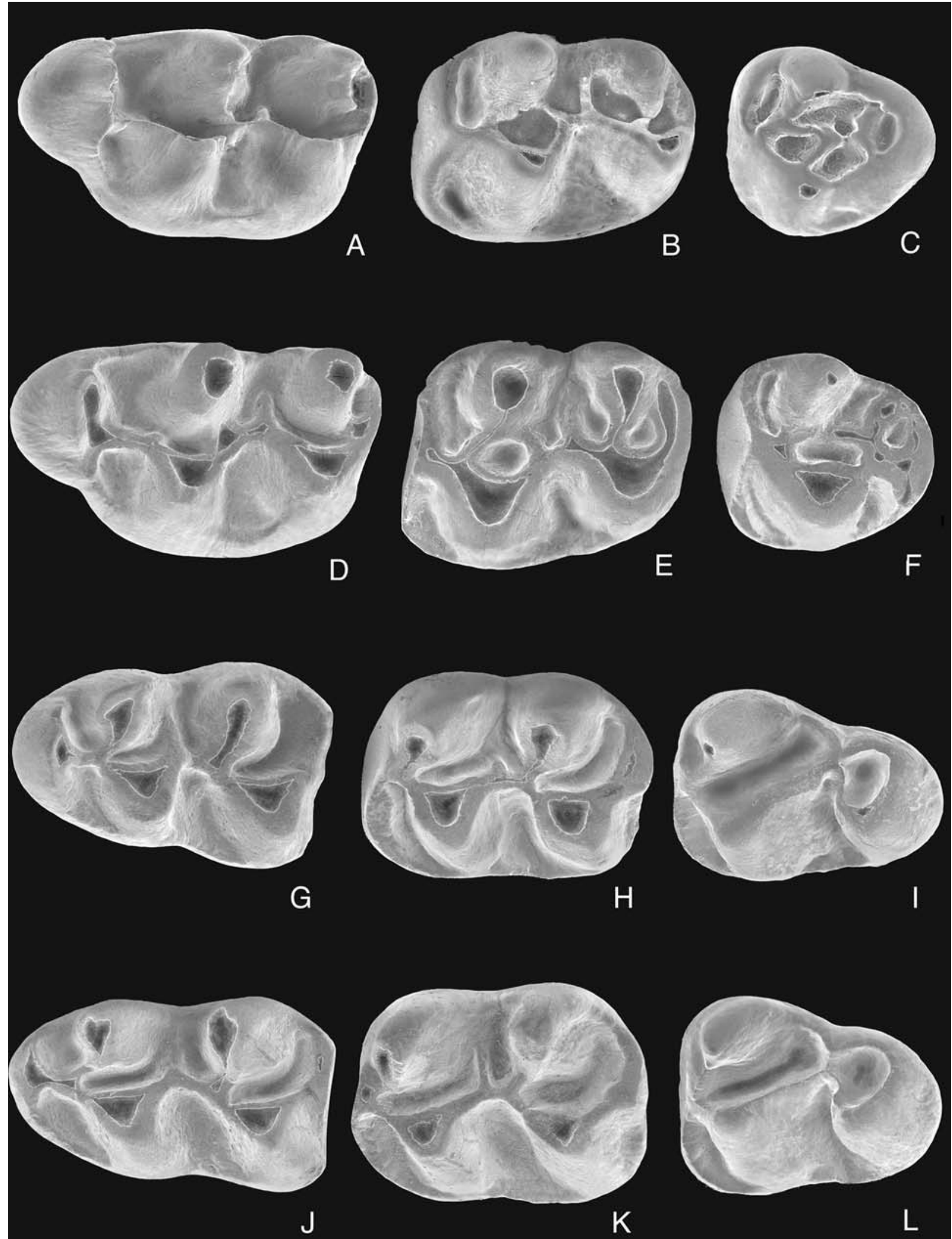

\section{$1 \mathrm{~mm}$}


Fig. 4 Molars (in occlusal view) of Democricetodon mutilus from Sandelzhausen (Southern Germany, MN5). A $\mathbf{M}^{1}$ (7011); $B \mathrm{M}^{2}$ (8000); $C \mathrm{M}^{3}$ (11203); $D \mathrm{M}^{1}$ (7364); $E \mathrm{M}^{2}$ (7976); $F \mathrm{M}^{3}$ (11193); $G$ $\mathrm{M}_{1}$ (7320); $H \mathrm{M}_{2}$ (7485); $I \mathrm{M}_{3}$ (10058); $J \mathrm{M}_{1}$ (7321); $K \mathrm{M}_{2}$ (7483); $L$ $\mathrm{M}_{3}$ (10063) All figured teeth are left specimens

just posterior to the point where the anterior part of the longitudinal crest joins the lingual border. Here the sinusid is deep. A short mesolophid-like ridge is present in 10. The sinusid has in 31 a ridge and in 6 a small cusp on its labial border.

\section{Discussion}

In the original description 148 molars from 6 localities were used, 40 of these were from Sandelzhausen. Now more then thousand molars from Sandelzhausen are available. The frequencies in which certain characters (mesoloph(id), protolophule) occur, differ somewhat from the original species description, these differences are considered real and not due to differences in morphological descriptions. In the original description the mesolophid and mesoloph from D. mutilus are short or medium in $\mathrm{M}_{1}$ and $\mathrm{M}_{2}$, and of medium length or long in $\mathrm{M}^{1}$ and $\mathrm{M}^{2}$. In our Sandelzhausen material the mesoloph is long in less then $40 \%$ in $\mathrm{M}^{1}$, and the mesoloph in $\mathrm{M}^{2}$ and mesolophid $\left(\mathrm{M}_{1}\right.$, $\mathrm{M}_{2}$ ) are in less than $30 \%$ of the molars long or connected to the lingual border. The protolophule in the $\mathrm{M}^{1}$ is in the original species description rarely double, but here the protolophule is double in $30 \%$ of the molars. These differences in frequencies are considered to be the result of the large difference in the number of specimens. Measurements of our material overlap completely the measurements of the original Sandelzhausen material.

Boon (1991) and Kälin (1997) state that a trend in size increase in $D$. mutilus is absent. The range in size in $D$. mutilus from Sandelzhausen overlaps almost completely all other D. mutilus measurements from other localities (probably due to the very large amount of molars), except for Puttenhausen, Germany (Wu 1982), where some smaller $\mathrm{M}_{2}$ and $\mathrm{M}^{3}$ molars are present. We can conclude that a pattern in size change, either spatial or temporal, is not apparent. Also a pattern in change in morphologies is not present, although Boon (1991) and Wu (1982) state that the length of the mesolophid $\left(\mathrm{M}_{1}\right)$ could be used as an evolutionary indicator (longer is more evolved). However, both authors emphasize that this interpretation is based on small collections only.

Genus Megacricetodon Fahlbusch 1964.

\section{Megacricetodon minor (Lartet 1851)}

Figure 5A-L.

1925 Cricetodon minus Lartet 1851.-SCHAUB: 15.

1963 Cricetodon minor minor LARTET.-Freudenthal: 36.

1964 Democricetodon (Megacricetodon) schaubi Fahlbusch: 65, text-Fig. 48.

1964 Democricetodon (Megacricetodon) aff. schaubi Fahlbusch: 66, text-Figs. 49-50.

Holotype

Left $\mathrm{M}_{1}-\mathrm{M}_{3}$ (Ss 1235) Museum Basel, Switzerland.

Type locality and type horizon

Sansan (France), Molasses de l'Armagnac, Middle Miocene, MN6.

Geographical distribution and biochronological range

France (MN5-7/8), Germany (MN5-7/8), Switzerland (MN5-7/8), Slovakia (MN6), Spain (MN6-7/8), and Hungary (MN6-7/8).

Table 2 Measurements (in $\mathrm{mm}$ ) of Democricetodon mutilus from Sandelzhausen

\begin{tabular}{|c|c|c|c|c|c|c|c|c|c|c|c|c|}
\hline \multicolumn{13}{|c|}{ Democricetodon mutilus } \\
\hline & \multirow[t]{2}{*}{ Total $(N)$} & \multicolumn{5}{|c|}{ Length } & \multirow[t]{2}{*}{$N$} & \multicolumn{5}{|c|}{ Width } \\
\hline & & Min & Mean & Max & SE & SD & & Min & Mean & Max & SE & SD \\
\hline$M^{1}$ & 184 & 1.73 & 1.95 & 2.16 & 0.007 & 0.085 & 154 & 1.13 & 1.30 & 1.44 & 0.004 & 0.056 \\
\hline $\mathrm{M}^{2}$ & 176 & 1.38 & 1.54 & 1.66 & 0.004 & 0.055 & 174 & 1.18 & 1.29 & 1.42 & 0.003 & 0.045 \\
\hline $\mathrm{M}^{3}$ & 122 & 0.98 & 1.09 & 1.23 & 0.005 & 0.054 & 114 & 1.05 & 1.13 & 1.24 & 0.004 & 0.045 \\
\hline $\mathrm{M}_{1}$ & 182 & 1.48 & 1.67 & 1.86 & 0.005 & 0.071 & 167 & 0.99 & 1.11 & 1.24 & 0.004 & 0.052 \\
\hline $\mathrm{M}_{2}$ & 217 & 1.37 & 1.52 & 1.68 & 0.004 & 0.058 & 208 & 1.10 & 1.24 & 1.39 & 0.004 & 0.056 \\
\hline$M_{3}$ & 160 & 1.21 & 1.37 & 1.49 & 0.005 & 0.059 & 156 & 0.94 & 1.11 & 1.24 & 0.005 & 0.059 \\
\hline
\end{tabular}




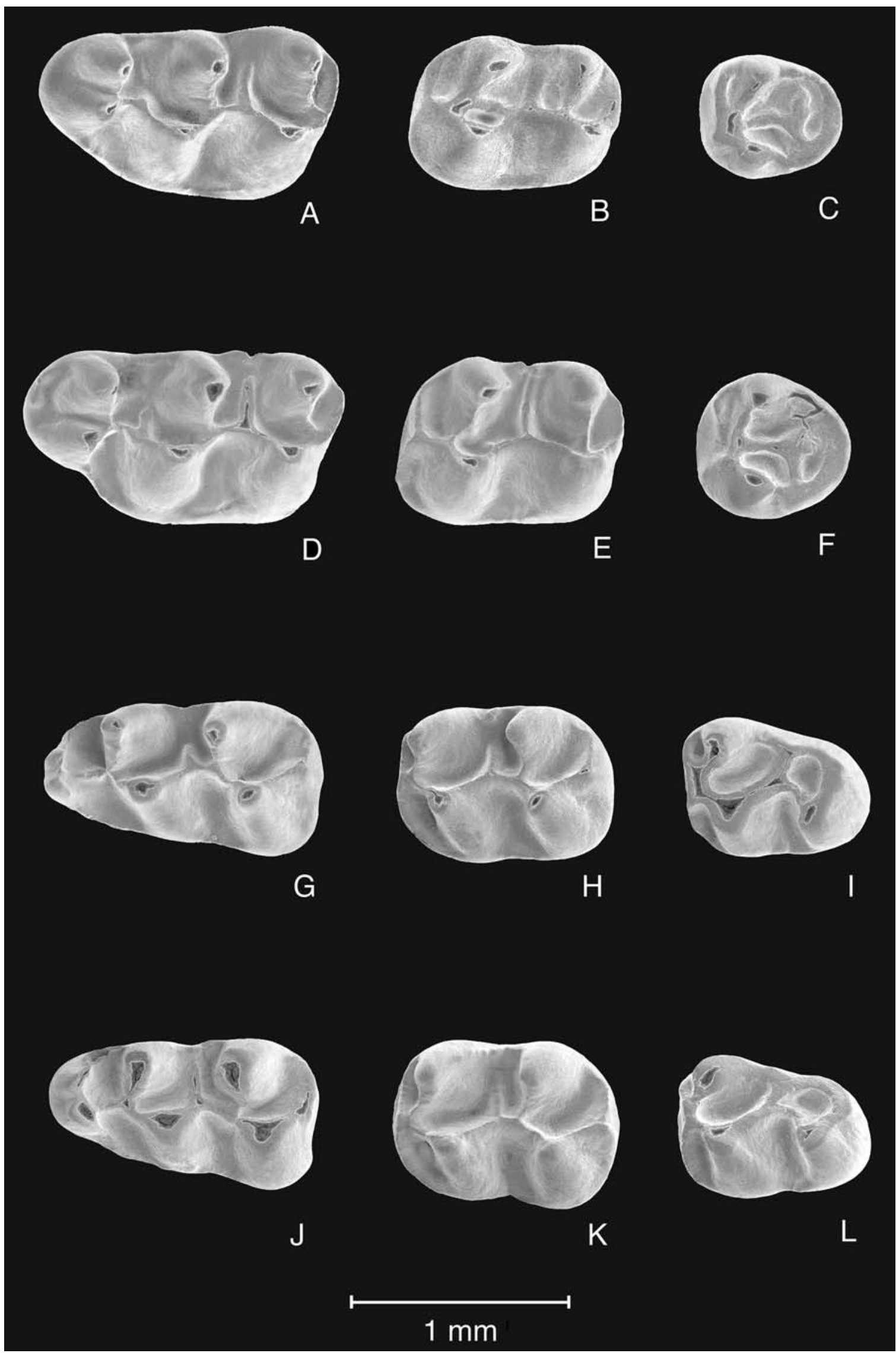


Fig. 5 Molars (in occlusal view) of Megacricetodon minor from Sandelzhausen (Southern Germany, MN5). A $\mathrm{M}^{1}$ (9220); $B \mathrm{M}^{2}$ (10945); $C \mathrm{M}^{3}$ (11015); $D \mathrm{M}^{1}$ (9221); $E \mathrm{M}^{2}$ (9639); $F \mathrm{M}^{3}$ (10972); $G$ $\mathrm{M}_{1}$ (9258); $H \mathrm{M}_{2}$ (10848); $I \mathrm{M}_{3}$ (10212); $J \mathrm{M}_{1}$ (9250); $K \mathrm{M}_{2}$ (10849); $L \mathrm{M}_{3}$ (10216) All figured teeth are left specimens

Material and measurements

323 molars, 301 complete and used in measurements and descriptions (see Figs. 2 and 5, Table 3.

$\mathrm{M}_{1}$ dex (5511-5512, 9274-9281, 9319, 9331, 1082210847); $\mathrm{M}_{1} \sin$ (9248-9273, 10798-10821, 10990); $\mathrm{M}_{2} \mathrm{dex}$ (9907-9910, 9912, 9914-9915, 10822-10823, 10876$10893) ; \mathrm{M}_{2} \sin (5513$, 9896-9902, 9904-9906, 10848$10855,10858,10860-10872,10874-10875) ; \mathrm{M}_{3} \operatorname{dex}$ (10227-10228, 10994); $\mathrm{M}_{3} \sin (10213,10216,10218-$ 10219, 10223); $\mathrm{M}^{1} \mathrm{dex}(5506,9229-9247,10916-10940)$; $\mathrm{M}^{1} \sin$ (9216-9228, 9282, 10894-10915, 6E); $\mathrm{M}^{2} \mathrm{dex}$ (5505, 9650-9661, 10954-10971); $\mathrm{M}^{2}$ sin (5507, 96399649, 9662, 9749, 10941-10953); $\mathrm{M}^{3}$ dex (10977-10984, $11030,11033,11035,11039-11040,11043) ; \mathrm{M}^{3} \sin$ (10972-10974, 11013, 11015-11016, 11018, 11020 , 11023, 7E).

For the description in Fahlbusch (1964) only 15 molars from Sandelzhausen were available.

\section{Description}

$\mathrm{M}^{1}(n=78)$ : The anterocone is for its largest part placed on the labial side of the tooth. The labial side of the outline is straight, the lingual side is convex with a smooth transition from anterocone to protocone in 69 , a shallow indentation near the protosinus is present in 9. The anterocone is unequally split in all specimens, the labial cusp is larger than the lingual one. A ridge or cusp on the anterior part of the anterocone is present in 46 (small in 36, large in 10). A labial anteroloph is absent, a lingual anteroloph is present in 12 and a small cusp is present in 12 on the postero-lingual side of the protocone. A labial spur of the anterolophule is long in 15 , short in 14 and absent in the other 49 (in 2 next to a long labial spur of the anterolophule a double protolophule is present). The protolophule is double in 8 and simple in 57 (where it is connected to the to the longitudinal crest behind the protocone). In 13 a short transverse spur is present in the anterosinus, but it is unclear whether it is a protolophule or a spur of the anterolophule. The metalophule is simple in all molars (in 4 anterior and connected to the longitudinal crest just anterior to the hypocone, in 7 transverse and connected to the hypocone, in 67 posterior and connected to the posteroloph). The mesoloph is short in 3, of medium length in 10 and long in 65 (in 29 connected to the labial border). A very short paracone spur is present in 16 . A protocone spur is absent. The sinus is slightly forwards directed in 10 and transverse in all the others. In most molars small accessory cusps are present: a very small cusp (12) or ridge (12) on the postero-lingual side of the protocone, a cusp (13) or ridge (17) on the antero-lingual side of the hypocone, a small ridge (9) on the labial border of the mesosinus and a cusp or ridge-like cusp in 49 on the labial border of the anterosinus.

$\mathrm{M}^{2}(n=54)$ : The lingual anteroloph is present in all but 9, and reaches antero-lingual base of the protocone. The labial anteroloph is long and joins the paracone. The protolophule is simple in 41 (anterior in 37 and connected to the antero-labial part of the protocone, in 4 transverse and connected to the protocone). A double protolophule is present in 13 (4 are incomplete). The metalophule is simple and present in all but 1 (anterior in 32, transverse in 12, posterior in 10). A mesoloph is short in 6 , of medium length in 8 and long in 40 (33 are connected to the labial border). A protocone spur is present in 1 , it connects the lower posterior part of the protocone to the lingual border of the sinus. A paracone spur is present in 10 , very short in 4 (just a thickening of the posterior side of the paracone), thin in 3 and ending in the mesosinus and in 3 thick and

Table 3 Measurements (in mm) of Megacricetodon minor from Sandelzhausen

\begin{tabular}{|c|c|c|c|c|c|c|c|c|c|c|c|c|}
\hline \multicolumn{13}{|c|}{ Megacricetodon minor } \\
\hline & \multirow[t]{2}{*}{ Total $(N)$} & \multicolumn{5}{|c|}{ Length } & \multirow[t]{2}{*}{$N$} & \multicolumn{5}{|c|}{ Width } \\
\hline & & Min & Mean & Max & SE & SD & & Min & Mean & Max & SE & SD \\
\hline$M^{1}$ & 82 & 1.27 & 1.39 & 1.57 & 0.006 & 0.058 & 78 & 0.70 & 0.85 & 0.97 & 0.006 & 0.049 \\
\hline $\mathrm{M}^{2}$ & 58 & 0.89 & 1.01 & 1.08 & 0.005 & 0.040 & 54 & 0.73 & 0.82 & 0.91 & 0.005 & 0.038 \\
\hline $\mathrm{M}^{3}$ & 24 & 0.63 & 0.71 & 0.78 & 0.001 & 0.039 & 21 & 0.59 & 0.67 & 0.71 & 0.008 & 0.036 \\
\hline $\mathrm{M}_{1}$ & 89 & 1.15 & 1.26 & 1.38 & 0.005 & 0.050 & 82 & 0.63 & 0.75 & 0.82 & 0.004 & 0.034 \\
\hline $\mathrm{M}_{2}$ & 62 & 0.94 & 1.02 & 1.10 & 0.005 & 0.038 & 58 & 0.70 & 0.81 & 0.89 & 0.005 & 0.038 \\
\hline $\mathrm{M}_{3}$ & 8 & 0.77 & 0.85 & 0.91 & 0.015 & 0.043 & 8 & 0.64 & 0.72 & 0.79 & 0.016 & 0.045 \\
\hline
\end{tabular}




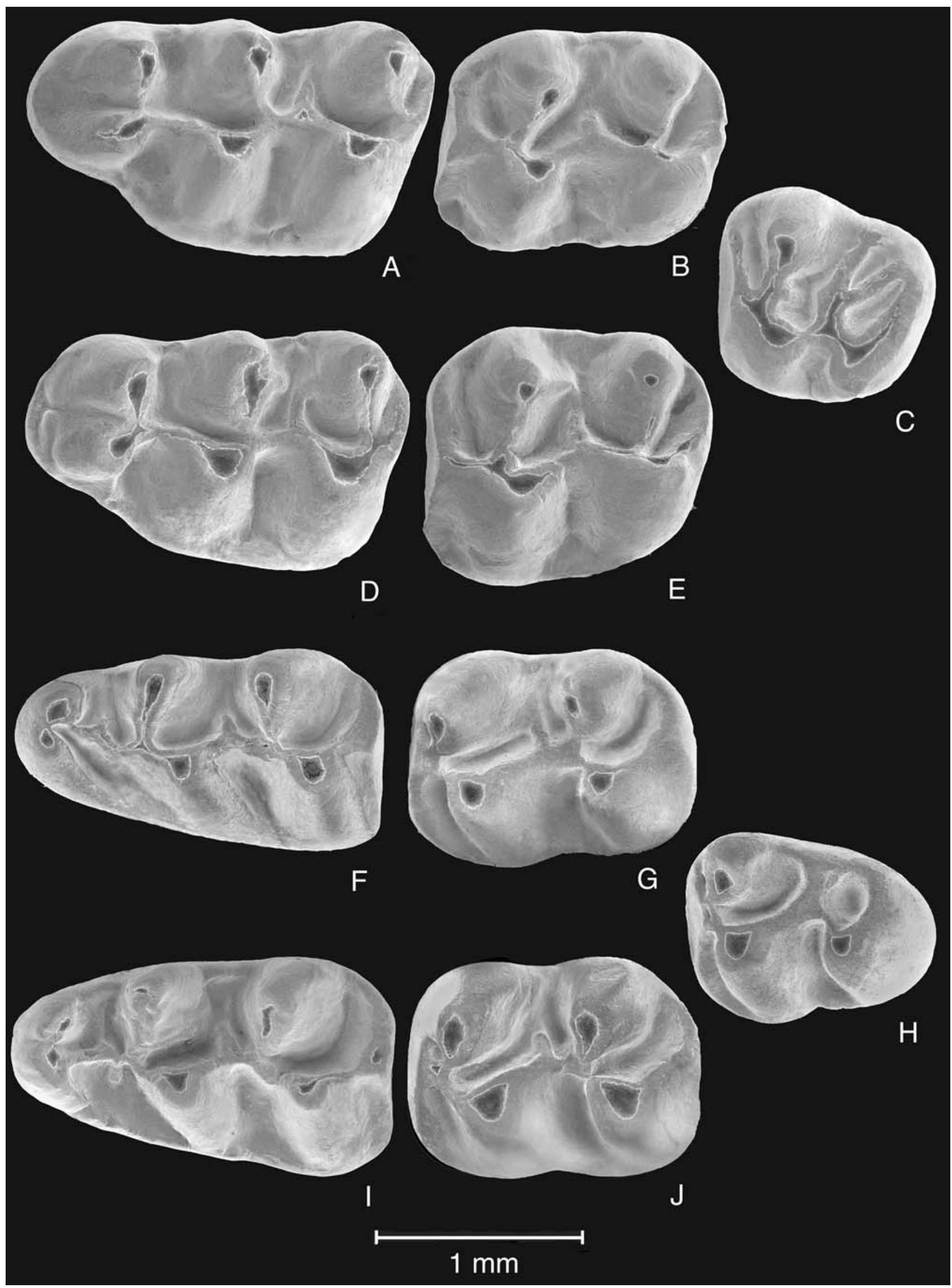


Fig. 6 Molars (in occlusal view) of Megacricetodon bavaricus from Sandelzhausen (Southern Germany, MN5). $A \mathrm{M}^{1}$ (11073) (figured inverse); $B \mathrm{M}^{2}$ (11078); $C \mathrm{M}^{3}$ (11088); $D \mathrm{M}^{1}$ (11067) (figured inverse); $E \mathrm{M}^{2}$ (11079); $F \mathrm{M}_{1}$ (11049); $G \mathrm{M}_{2}$ (11062) (figured inverse); $H \mathrm{M}_{3}$ (10991); $I \mathrm{M}_{1}$ (11048); $J \mathrm{M}_{2}$ (11064) (figured inverse) All teeth are figured as left specimens, right ones are indicated by (inverse)

connected to the mesoloph. The sinus shows a large variation, forwards in 21, transverse in 27 and backwards in 6 . A low ridge on the lingual border of the sinus is present in 6 . In all but 1 a small cusp or small ridge is present on the labial border of the meso-sinus.

$\mathrm{M}^{3} \quad(n=21)$ : Small semi-quadrangular molars. The labial anteroloph is long and joins the paracone, a lingual anteroloph is present in 1 molar only. The protolophule is always simple, slightly forwards directed and connects paracone to protocone. A hypocone is large in all, it is placed near to the protocone on the lingual side of the molar, giving the molar its quadrangular outline. A very small metacone is distinguishable in 2 molars only. The metalophule connects hypocone to the postero-labial corner in 18 , in 3 the metalophule ends in the mesosinus. A ridge between paracone and metalophule is present in 15 (in 4 incomplete). The connection between protocone and hypocone is always present. A small sinus is present in 16 and absent in 5 .

$\mathrm{M}_{1}(n=82)$ : The anteroconid is never completely separated into two cusps, it is semi-split in 65 and in the other 27 only the upper part of the anterocone is divided, which disappears in early wear. A lingual anterolophid is absent, but a short ridge or cusp-like ridge on the border of the anterosinusid is always present. The labial anterolophid is always present, but never joins the protoconid. The anterolophulid connects the labial part of the anteroconid to the protocone. A short labial spur of the anterolophulid is present in 2 and a short lingual spur in 3. An extra ridge between metaconid and anteroconid is present in 1. A simple anterior metalophulid is present in all. The hypolophulid is anterior in 28 and transverse in 54. The mesolophid is absent in 2, short in 21 , of medium length in 24 and long in 35 (30 to border). A small spur of an ectomesolophid is present in 1 . The sinusid is in all forwards directed.

$\mathrm{M}_{2}(n=58)$ : The labial anterolophid reaches almost the basis of the protoconid. The lingual anterolophid is long in 53 and joins the antero-lingual border of the paracone, it is short in 4 and absent in 1 . The short metalophulid is forwards directed and connected to the anterolophid. The hypolophulid is short and in all forwards directed. The mesolophid is absent in 5, short in 18 , of medium length in
18 and long in 17 (8 to border). An ectomesolophid is absent. The sinusid is forwards directed. In 4 a minor mesostylid is present.

$\mathrm{M}_{3}(n=8)$ : The labial anterolophid is connected to the antero-labial border of the protoconid. The lingual anterolophid reaches the anterior part of the paracone. The metalophulid is very short. The longitudinal crest is semicircular and is connected to the lingual border of the molar by a short hypolophulid. A small entoconid is present in 1 . The sinusid is transverse in 3 and slightly backwards directed in 5. A mesolophid is absent.

Discussion The size ranges of all the molars of M. minor from Sandelzhausen are comparable with those of Mohrenhausen (Germany), slightly smaller or comparable with those of Sansan (France), and slightly larger than the molars from Giggenhausen (Germany) and Anwil (Swiss) (Boon 1991). All these localities are younger than Sandelzhausen. The size range of $M$. minor shows some variation, but doesn't show a clear trend in size variation during time.

The presence of a spur of the anterolophule shows a large variation, for example in Sandelzhausen it is $37 \%$, in younger assemblages as Sansan (type material) it is $24 \%$, in Ebershausen (Ger) 4\% and in Giggenhausen 56\% (Boon 1991).

The small Megacricetodon minor from Sandelzhausen was originally assigned to M. aff. minor (Fahlbusch 1964), because its measurements fall slightly below or in the lower half of the size range of the type material from Sansan (France). However, neither an apparent trend in size increase through time nor an evolutionary trend in the expression of some of the morphologies (mesoloph(id), labial spur anterolophule) is apparent in M. minor (Boon 1991). The small difference in average sizes in the Sandelzhausen molars compared to the type specimens does not warrant a separate taxonomical position, the Sandelzhausen molars (more than 300) should therefore be named M. minor.

\section{Megacricetodon bavaricus Fahlbusch 1964}

Figure 6A-J.

*1964 Democricetodon (Megacricetodon) gregarius bavaricus Fahlbusch: 51, text-Figs. 34-39, pl. 5.

1964 Democricetodon (Megacricetodon) gregarius aff. bavaricus Fahlbusch: 59, text-Figs. 41-46, pl. 6 Figs. 121.

1982 Megacricetodon germanicus Aguilar 1980.-Wu: 49, text-Figs. 6 and 7.

1991 Megacricetodon germanicus Aguilar 1980.Boon: 42, text-figs. 11-15, pl. 3 figs. 1-12. 
Table 4 Measurements (in mm) of Megacricetodon bavaricus from Sandelzhausen

\begin{tabular}{|c|c|c|c|c|c|c|c|c|c|c|c|c|}
\hline \multicolumn{13}{|c|}{ Megacricetodon bavaricus } \\
\hline & \multirow[t]{2}{*}{ Total $(N)$} & \multicolumn{5}{|c|}{ Length } & \multirow[t]{2}{*}{$N$} & \multicolumn{5}{|c|}{ Width } \\
\hline & & Min & Mean & Max & SE & SD & & Min & Mean & $\operatorname{Max}$ & SE & SD \\
\hline$M^{1}$ & 9 & 1.92 & 2.04 & 2.15 & 0.030 & 0.080 & 7 & 1.24 & 1.30 & 1.41 & 0.023 & 0.060 \\
\hline $\mathrm{M}^{2}$ & 11 & 1.40 & 1.46 & 1.53 & 0.015 & 0.048 & 10 & 1.15 & 1.25 & 1.30 & 0.015 & 0.046 \\
\hline $\mathrm{M}^{3}$ & 6 & 0.93 & 1.09 & 1.25 & 0.066 & 0.148 & 5 & 0.91 & 1.03 & 1.10 & 0.032 & 0.073 \\
\hline $\mathrm{M}_{1}$ & 13 & 1.80 & 1.91 & 2.05 & 0.024 & 0.072 & 9 & 1.00 & 1.12 & 1.17 & 0.020 & 0.059 \\
\hline $\mathrm{M}_{2}$ & 7 & 1.47 & 1.52 & 1.54 & 0.013 & 0.029 & 5 & 1.17 & 1.21 & 1.28 & 0.019 & 0.043 \\
\hline $\mathrm{M}_{3}$ & 1 & & 1.21 & & & & 1 & & 1.21 & & & \\
\hline
\end{tabular}

\section{Holotype}

M1 sin, (1951 XXVII 180) BSPG, Munich, Germany.

Type locality and type horizon

Langenmoosen near Neuburg/Donau, Germany, OSM (Upper Freshwater Molasse), Middle Miocene, MN5.

Geographical distribution and biochronological range

Switzerland (MN4-5), France (MN5), Germany (MN5).

\section{Material and measurements}

47 molars, 37 complete and used in measurements and descriptions (see Figs. 2 and 6, Table 4).

$\mathrm{M}_{1} \operatorname{dex}(11056-11060) ; \mathrm{M}_{1} \sin (11048-11055) ; \mathrm{M}_{2} \operatorname{dex}$ (11062-11066), $\mathrm{M}_{2} \sin$ (11047, 11061); $\mathrm{M}_{3} \sin$ (10991); $\mathrm{M}^{1} \operatorname{dex}(11070-11075) ; \mathrm{M}^{1} \sin (11067-11069) ; \mathrm{M}^{2} \mathrm{dex}$ (11083-11086); $\mathrm{M}^{2} \sin (11076-11082) ; \mathrm{M}^{3} \operatorname{dex}(11096$, 11098, 8E); $\mathrm{M}^{3} \sin (11017,11022,11024)$.

In 1964, Megacricetodon bavaricus was not known from the assemblage of Sandelzhausen. Now 46 molars from Sandelzhausen are assigned to this species.

\section{Description}

$\mathrm{M}^{1}(n=7)$ : The anterocone is unequally split in all, the labial cusp is larger than the lingual one. A ridge or cusp on the anterior part of the anterocone is always present, it can be small or large (see Plate IV). A labial spur of the anterolophule is absent. The protolophule is double in 1, and simple in the other 6 where it is connected to the longitudinal crest behind the protocone. The metalophule is simple in all and connected to the posteroloph. The mesoloph is present in all, short in 1, of medium length in 4 and long in 2 (in 1 connected to the labial border). In most molars small accessory cusps are present: on the lingual border of the lingual anterocone cusp in 4, in all molars a very small cusp on the postero-lingual side of the protocone, in all a larger cusp on the antero-lingual side of the hypocone (in 1 connected by a ridge to the anterior side of the hypocone), a small mesotyle (4) or ridge (3) on the labial border of the mesosinus and a cusp or ridge-like cusp on the labial border of the protosinus. A protocone spur is absent. A paracone spur is present in one, it is very short. The sinus is forwards directed in 1 and transverse in 6 .

$\mathbf{M}^{2}(n=10)$ : The lingual branch of the anteroloph is present in 8 , and reaches the antero-lingual base of the protocone. It is absent in 2 . The labial anteroloph joins the antero-labial side of the paracone. The protolophule is single in all (in 8 forwards directed and connected to the antero-labial part of the protocone, in 2 transverse and connected to the protocone). The metalophule is simple and present in all (slightly anterior in 5 , transverse in 2 , and posterior in 3). A mesoloph is absent in 1, short in 6 and of medium length in 3 (these are connected to the paracone spur). A low ridge on the lingual border of the sinus is present in 6. In all but 1 a small cusp or small ridge is present on the labial border of the mesosinus. A protocone spur is present in 1, it connects the posterior lower part of the protocone to the lingual border of the sinus. A paracone spur is present in all 10 molars, very short in 4 (just a thickening of the posterior side of the paracone), in 3 thin and short but ending in the mesosinus and in 3 thick and connected to the mesoloph. The sinus shows a large variation, forwards in 3, transverse in 5 and backwards in 2 .

$\mathrm{M}^{3}(n=5)$ : A poorly developed lingual anteroloph reaches the basis of the protocone in 1 and is absent in 4 . The labial anteroloph joins the antero-labial side of the paracone. A hypocone is large in all, it is near to the protocone on the lingual side of the molar, giving the molar a quadrangular outline. A small metacone is distinguishable in 2 molars only. The protolophule is transverse in 2 , slightly forwards in 3 and connects paracone to protocone. The metalophule connects hypocone to metacone (2) or to the postero-labial corner (3). A ridge connects paracone to 
metalophule in 1. A mesoloph connects in 2 metalophule to labial border, in 2 it ends free in the mesosinus. The connection between protocone and hypocone is strong in 2 , weak in 2 and absent in 1 (then sinus is deep).

$\mathrm{M}_{1}(n=9)$ : The anteroconid is never completely separated into two cusps, it is semi-split in 7 and in the other 2 only the upper part of the anterocone is divided which disappears in early wear. A short labial spur of the anterolophulid is present in 2 and a short lingual spur in 3 . The lingual anterolophid is absent, the labial anterolophid joins the protoconid in 2 , is short in 5 and absent in 2 . An extra ridge between metaconid and anteroconid is present in 1. An anterior metalophulid is present in all. The hypolophulid is either anterior (3) or transverse (6). The mesolophid is absent in 2, short in 6 and of medium length in 1 . A small spur of an ectomesolophid is present in 1. The sinusid is forwards directed in 8 and transverse in 1. A mesostylid is present in 1 and a ridge on the border of the mesosinusid in 1 .

$\mathrm{M}_{2}(n=5)$ : The labial anterolophid is connected to the antero-labial base of the protoconid. The lingual anterolophid is short. The metalophulid is very short, forwards directed and connected to the anterolophid. The hypolophulid is short in all and forwards directed. The mesolophid is absent in 2, short in 2 and of medium length in 1 . The sinusid is transverse in 1 and backwards directed in 4. An ectomesolophid is absent. In 1 a minor mesostylid is present.

$\mathrm{M}_{3}(n=1)$ : The labial anterolophid is connected to the antero-labial border of the protoconid. The lingual anterolophid is very short, it will fuse in medium wear with the metaconid. The metalophulid is very short. A hypolophulid connects the longitudinal crest to the lingual border of the molar. An entoconid is absent. The sinusid is slightly backwards directed. A mesolophid is absent.

\section{Discussion}

In 1964, Fahlbusch described $M$. bavaricus and $M$. aff. bavaricus from the Upper Freshwater Molasse, the latter species only differing is size (by being larger). New excavations in Sandelzhausen added M. aff. bavaricus to the fauna list of Sandelzhausen (Fahlbusch 2003).

Megacricetodon germanicus Aguilar 1980 was described from the German localities Puttenhausen (Wu 1982), Edelstetten, Bubenhausen and Betlinshausen (Boon 1991), but Heissig (1997) determined this material as $M$. aff. germanicus because of the uncertainties in the correct interpretation of M. germanicus. Also Kälin (1997) considers the use of $M$. germanicus not valid for material from the German and Swiss MN5 and MN6 assemblages. Morphologically $M$. bavaricus and $M$. germanicus are difficult to separate; $M$. bavaricus has in general a longer mesolophid and may have a spur on the anterolophulid (Boon 1991). M. germanicus has a simple undivided anteroconid and further a simple morphology: short mesoloph(id)s and absence of anterolophule(id) spurs (Boon 1991; Kälin 1997).

We follow Kälin (1997) in the distinction of two Megacricetodon lineages in the Swiss assemblages. The lineage $M$. collongensis Mein 1958-M. bavaricus-M. aff bavaricus-M. lappi Mein 1958 occurring in MN4 to MN5 assemblages, is characterized by a gradual increase of size. The second lineage, M. germanicus, occurring in MN6 to MN8 assemblages, does not show a variation in size.

M. bavaricus molars from several assemblages from the Upper Freshwater Molasse show that the variation in size in all molar elements is large (Boon 1991; Heissig 1997). Especially in the assemblage of Betlinshausen (Boon 1991) where it overlaps the size range of the type species from Langenmoosen and also the size range from Puttenhausen and Gisseltshausen (all German localities).

A size increase in a short time is not uncommon in cricetids (van Der Meulen et al. 2003), and does not warrant distinction in many different species. Therefore, all the material described as $M$. aff. bavaricus from several German localities is included in M. bavaricus.

\section{Distribution and palaeoecology}

Democricetodon gracilis is common in middle and South Eastern European MN4 and MN5 assemblages and present in eastern European MN6-7/8 assemblages. D. gracilis seems to be related to D. franconicus Fahlbusch 1966, which has its origin probably in Turkey (Theocharopoulos 2000). D. franconicus migrates several times into Europe, where it evolves in other species, such as D. hispanicus Freudenthal 1967 in Spain, D. koenigswaldi (Freudenthal 1963) in Spain, and probably also in D. gracilis (MN4 Greece; Theocharopoulos 2000).

D. mutilus is also regarded to be a descendant of $D$. franconicus, and is known from MN4-5 assemblages in France, and is present in many middle European MN5 assemblages. It is in MN6 present in Germany and Switzerland, and in $\mathrm{MN} 7 / 8$ it is limited to German and Hungarian assemblages. It is part of the lineage $D$. franconicus- D. mutilus which is, according to Kälin (1997), not useful as a stratigraphical marker since it does not display a regular size increase.

D. mutilus and D. koenigswaldi are similar in size and show only minor morphological differences (D. koenigswaldi has a higher frequency of the double metalophule in the $\mathrm{M}^{2}$ and has shorter mesoloph(id)s) (van Der Meulen et al. 2003). It is not clear what the relation is between these two species.

The earliest occurrence of Megacricetodon minor is reported from middle European MN5, it occurs more 
westwards during MN6 (Spain) and occurs in middle and eastern Europe in MN6 and MN7/8. Its origin is unknown, it seems to be an immigrant from the east, but whether its distribution is the result of several migration waves or of regional expansion is not clear.

Megacricetodon bavaricus occurs for the first time in Switzerland in MN4 and is common in many German and Swiss MN5 assemblages. M. bavaricus is part of the lineage $M$. collongensis-M. lappi, which shows a constant size increase during time (Kälin 1997).

Hamsters with a complex dental pattern are considered to be inhabitants of relative wet biotopes (Daams et al. 1999). The length of the mesoloph in the second upper molars is considered to be a good indicator of habitat. Species with a mesoloph to the border of the tooth (which should be present in more than $25 \%$ of the $\mathrm{M}^{2}$ ) are considered to indicate a humid environment. Using this method for the Sandelzhausen hamsters, it appears that $M$. minor and D. gracilis had a preference for a humid habitat (>60\% with long mesoloph). D. mutilus (11\% with mesoloph to border) and M. bavaricus ( $0 \%$ with mesoloph to border) had a preference for drier habitats.

Daams et al. (1999) consider M. minor in Spain as an indicator of a humid environment, but Kälin (1999) doubts whether the interpretation for the Spanish hamsters can be extrapolated to Swiss material. He mentions a probable different biotope preference in the Swiss hamsters, where M. minor is considered to be an opportunistic species without an outspoken habitat preference and where large Megacricetodon species are considered to have lived on the distal areas of alluvial fans.

Acknowledgments V. Fahlbusch and G. Rössner (both Munich) invited us to work on the Sandelzhausen material. K. Heissig (Munich) provided important information on the Upper Freshwater Molasse and A. van der Meulen (Utrecht) provided valuable information on Democricetodon. Valuable comments from K. Heissig (Munich) and P. Peláez Campomanes (Madrid) improved the manuscript. The Deutsche Forschungsgemeinschaft (DFG) provided funding to attend the Sandelzhausen Symposium 2005 in Mainburg (GZ-4850/88/05).

Open Access This article is distributed under the terms of the Creative Commons Attribution Noncommercial License which permits any noncommercial use, distribution, and reproduction in any medium, provided the original author(s) and source are credited.

\section{References}

Aguilar, J.-P. 1980. Nouvelle interpretation de l'évolution du genre Megacricetodon au cours du Miocène. Palaeovertebrata, Memoire Jubileum R. Lavocat: 335-364.

Boon, E. 1991. Die Cricetiden und Sciuriden der Oberen SüsswasserMolasse von Bayerischen Schwaben und ihre Stratigraphische bedeutung. 143 p., Inaugural-Dissertion, Munich (Unpublished).
Bowdich, T.E. 1821. An analysis of the natural classification of Mammalia: for the use of students and travellers. 115 pp, Paris (J. Smith Print).

Bruijn, H. de 2009 this volume. The Eumyarion (Mammalia, Rodentia, Muridae) assemblage from Sandelzhausen (Miocene, Southern Germany), a test on homogeneity. In Rössner, G.E. \& Göhlich, U.B.: Fossil lagerstätte Sandelzhausen (Miocene, southern Germany): Contributions to the fauna. Paläontologische Zeitschrift 83(1): 000-000.

Daams, R., and M. Freudenthal. 1988. Megacricetodon (Cricetidae) from the Aragonian and the Lower Vallesian of the CalatayudTeruel basin. In Freudenthal, M., ed. Biostratigraphy and paleoecology of the Neogene micromammalian faunas from the Calatayud-Teruel basin (Spain). Scripta Geologica, special issue 1: 39-132.

Daams, R., A.J. Meulen, P. van der Peláez-Campomanes, and M.A. Alvarez-Sierra. 1999. Trends in rodent assemblages from the Aragonian (early- middle Miocene) of the Calatayud-Daroca basin, Aragon, Spain. In Hominoid evolution and climatic change in Europe, Vol. 1. The evolution of Neogene terrestrial ecosystems in Europe, ed. J. Agustí, and L. Rook, 127-139. Cambridge: Cambridge University Press.

Dehm, R. 1961. Über neue tertiäre Spaltenfüllungen des süddeutschen Jura- und Muschelkalkgebietes. Mitteilungen der Bayerischen Staatssammlung für Paläontologie und historische Geologie 1: 27-56.

Fahlbusch, V. 1964. Die Cricetiden (Mammalia) der Oberen Süsswasser-Molasse Bayerns. Abhandlungen der Bayerische Akademie der Wissenschaften (N. F) 118: 1-136.

Fahlbusch, V. 1966. Cricetidae (Rodentia, Mamm.) aus der mittelmiocänen Spaltenfüllung Erkertshofen bei Eichstatt. Mitteilungen der Bayerischen Staatssammlung für Paläontologie und historische Geologie 6: 109-131.

Fahlbusch, V. 2003. Die miozäne Fossil-Lagerstätte Sandelzhausen. Die Ausgrabungen 1994-2001. Zitteliana A 43: 109-121.

Fortelius, M., 2003. Neogene of the old world database of fossil mammals (NOW). University of Helsinki. http://www.helsinki. fi/science/now/.

Freudenthal, M., 1963. Entwicklungsstufen der miozänen Cricetodontinae (Mammalia, Rodentia) Mittelspaniens und ihre stratigraphische Bedeutung. Wageningen, 107.

Freudenthal, M. 1967. On the mammalian fauna of the Hipparionbeds in the Calatayud-Teruel Basin (prov. Zaragoza, Spain). Part 3: Democricetodon and Rotundomys (Rodentia). Proceedings of the Koninklijke Nederlandse Akademie van Wetenschappen $B$ 70(3): 298-315.

Freudenthal, M., and R. Daams, 1988. Democricetodon, Fahlbuschia, Pseudofahlbuschia nov. gen., and Renzimys from the Aragonian and the lower Vallesian of the Calatayud-Teruel Basin. In Freudenthal, M. (ed) Biostratigraphy and paleoecology of the Neogene micromammalian faunas from the Calatayud-Teruel basin (Spain). Scripta Geologica, special issue 1: 133-252.

Heissig, K. 1997. Mammal faunas intermediate between the reference faunas of MN4 and MN6 from the Upper Freshwater Molasse of Bavaria. In Aguilar, J.-P., Legendre, S., Michaux, J. (eds) Actes du Congrès BiochroM'97. Mémoires et Travaux de 1' E.P.H.E., Institut de Montpellier 21: 537-546.

Hír, J. 2004. The present status of the study on the Middle Miocene Rodent faunas in the Carpathian basin. Courier Forschungsinstitut Senckenberg 249: 45-52.

Illiger, C. 1811. Prodomus systematicus mammalium et avium additis terminis zoographicis utriusque clasis. Berlin: C. Salfeld.

Kälin, D. 1997. The mammal zonation of the upper marine molasse of Switzerland reconsidered. A local biozonation of MN2-MN5. In Aguilar, J.-P., Legendre, S., Michaux, J. (eds) Actes du Congrès 
BiochroM'97. Mémoires et Travaux de 1' E.P.H.E., Institut de Montpellier 21: 515-536.

Kälin, D. 1999. Tribe Cricetini. In The Miocene land mammals of Europe, ed. G.E. Rössner, and K. Heissig, 373-388. Munich: Verlag Dr. F. Pfeil.

Lartet, E. 1851. Notice sur la colline de Sansan. Auch, 45 p.

Mein, P. 1958. Les mammifères de la faune sidérolithique de VieuxCollonges. Nouvelles Archives du Muséum d'Histoire naturelle de Lyon 5: 1-122.

Mein, P., and M. Freudenthal. 1971. Les Cricetidae (Mammalia, Rodentia) du Neogéne Moyen de Vieux-Collonges. Part. 1: Le genre Cricetodon Lartet, 1851. Scripta Geologica 5: 1-51.

Meulen, A.J. van der, Peláez-Campomanes, P., Daams, R. 2003. Revision of medium-sized Cricetidae from the Miocene of the Daroca-Villafeliche area in the Calatayud-Teruel basin (Zaragoza, Spain). Coloquios de Paleontologia, Volume extraordinaire 1: 385-441.

Moser, M., G.E. Rössner, U.B Göhlich, M. Böhme, and V. Fahlbusch. 2009, this volume. The fossil lagerstätte Sandelzhausen (Miocene; southern Germany): history of investigation, geology, fauna and age. In Rössner, G.E., Göhlich, U.B. (eds) Fossil lagerstätte Sandelzhausen (Miocene, southern Germany): contributions to the fauna. Paläontologische Zeitschrift 83(1):000000 .

Schaub, S. 1925. Die hamsterartigen Nagetiere des Tertiärs und ihre lebenden Verwandten. Abhandlungen der Schweizerische Paläontologischen Gesellschaft 45: 1-114.

Schötz, M. 1993. Zwei hamsterfaunen (Rodentia, Mammalia) aus der niederbayerischen Molasse. Mitteilungen der Bayerischen Staatssammlung für Paläontologie und historische Geologie 33: 155-193.

Thaler, L. 1966. Les rongeurs fossils du Bas-Languedoc dans leur rapports avec l'histoire des faunes et la stratigraphy d'Europe. Mémoires de la Muséum National de Histoire Naturelle (C) 17: $1-295$.

Theocharopoulos, C.D. 2000. Late Oligocene-Middle Miocene Democricetodon, Spanocricetodon and Karydomys n. gen. from the eastern Mediterranean area. GAIA 8: 1-114.

Wu, W. 1982. Die Cricetiden (Mammalia, Rodentia) aus der Oberen Süsswasser-Molasse von Puttenhausen (Niederbayern). Zitteliana 9: 1-18. 